\title{
Introduction: Operationalizing Food Justice and Sustainability
}

\author{
Deric Shannon ${ }^{1}$
}

This paper argues that we might take ideas about food justice and sustainability and make them useful by rooting them in a web of ideas stressing opposition to structured inequalities. In addition, we might emphasize the creation of participatory relations of mutual aid and cooperation. Thus, by operationalizing food justice and sustainability as concepts that are intimately tied together, we can find a common ethical core and grow those interconnections outward. [Article copies available for a fee from The Transformative Studies Institute. E-mail address:_ journal@transformativestudies.org Website: http://www.transformativestudies.org (C2014 by The Transformative Studies Institute. All rights reserved.]

KEYWORDS: Food Justice, Sustainability, Racism, Inequality, Food Studies, Food Sovereignty, Food Security.

Social scientists often use the term "operationalize" to mean defining a variable in a precise way so that it can be properly measured. This form of the word means that we take a variable and make it empirically useful.

\footnotetext{
${ }^{1}$ Deric Shannon, Ph.D., is a former line cook, convenience store clerk, and fast food worker, now an Assistant Professor of Sociology at Oxford College of Emory University. He is the editor of The End of the World As We Know It? Crisis, Resistance, and the Age of Austerity and co-author of Political Sociology: Oppression, Resistance, and the State. His current research focuses on global political economy, the sociology of food, and ecology. Address correspondence to: Deric Shannon, Oxford College of Emory University; e-mail: deric.shannon@emory.edu. Acknowledgements : Thanks and acknowledgements are due, first and foremost, to Dr. John Asimakopoulos, the Transformative Studies Institute, and Theory in Action. Without their willingness to pursue and publish ethically engaged and challenging scholarship, this special issue would not have been possible. Secondly, I am indebted to Oxford College of Emory University's Faculty Development Committee and Office of Academic Affairs for funding to travel to the $3^{\text {rd }}$ Annual International Food Studies Conference in Austin and to the 2014 Conference of the Eastern Sociological Society, where I met scholars who contributed to this collection, as well as presenting my own research on food justice and sustainability. Finally, thanks are due to my friends, colleagues, and networks of mutual aid, all of whom helped me think through much of this material, read and edited submitted pieces, commented on my own work, and who have constantly reminded me that there is no such thing as a "single author" despite the continued persistence of that particular academic delusion.
} 